\title{
GLUCOSE CONSUME AND GROWTH OF E. coli UNDER ELECTROMAGNETIC FIELD
}

\author{
Luiz F.C. NASCIMENTO(1,2), Galdenoro BOTURA Jr.(3) \& Rogério P. MOTA(4)
}

\begin{abstract}
SUMMARY
E. coli was submitted to a $5 \mathrm{G}$ electromagnetic field generated by a alternate $60 \mathrm{~Hz}$ voltage source. The differences on growth and glucose consume in control and exposed groups were evaluated using the non-parametric Mann-Whitney U-test. There was a significant difference in glucose consume and growth in E. coli after 8 hours of exposition to electromagnetic field. It can be concluded that electromagnetic field had a positive effect in consume of glucose and growth of $E$. coli. The cause of these results can be explained by an increasing of glucose entrance through membrane due to the stimulated transport system via Facility Diffusion or cyclotron resonance. The growth can be caused by shortening of lag phase and excitement of log phase.
\end{abstract}

KEYWORDS: Electromagnetic field; Glucose consume; E. coli growth; Log phase; Special resonance.

\section{INTRODUCTION}

Life on Earth evolved in the presence of an incessant flux of a natural electromagnetic radiation such as solar radiation and the one deriving from electrical discharges. In the last sixty years an exponential increase of systems occurred, producing unnatural Electromagnetic Fields (EMF).

In contrast to the fields used in clinical practice, these fields normally encountered by the population, are much lower in magnitude and frequency and they come from power distribution systems. The intensity of these fields is around $0.1 \mathrm{G}$ but can reach $1 \mathrm{G}$ (in comparing, Earth's magnetic field is around $0.5 \mathrm{G})^{4}$.

It is known that the exposure to high intensity EMF in human being can produce several adverse effects such thermal injuries, seizures, nervous and muscle cell excitement; more recently, many studies showed that the association between EMF and childhood cancers such as leukemia, lymphoma and brain tumors ${ }^{7}$ and immune system effects with altered number of natural killer cells ${ }^{11}$, cardiac effects ${ }^{8}$ and efflux of calcium ions from brain tissue ${ }^{2}$.

In terms of the EMF action in microorganisms as bacteria, some papers have related some alterations in the growth and in the development of bacteria when submitted to several $\mathrm{GHz}$ frequency intensity fields ${ }^{3}$ and also a more intense $E$. coli growth when submitted to a $21.5 \mathrm{mG}$ static EMF. In this situation, the maximal growth of $E$. coli occurred at $100 \mathrm{~Hz}$ when compared to $10 \mathrm{KHz}$ and $1 \mathrm{MHz}^{6}$. Both papers describe EMF constant intensity during experiments.
This paper has the objective to show the effects of EMF generated by alternate tension in growth and consume of glucose by $E$. coli.

\section{MATERIALS AND METHODS}

E. coli strain ATCC 25922 was seeded ascetically, by inoculation, in 13 tubes and their corresponding pairs in an appropriate environment with glucose (Broth-Glucose, Merck ${ }^{\mathrm{TM}}$ ). The tubes had the same quantity of $E$. coli colonies and they were named Control (C) and Exposed (E). In the next step, the tubes named Exposed were put into coil, which was connected to alternate $60 \mathrm{~Hz}$ voltage source, under 5G EMF intensity.

The optical transmittance measurement was made initially and after $8 \mathrm{~h}$ of exposure to evaluate the growth of $E$. coli. The measures were made in Photometer National ${ }^{\mathrm{TM}}$ at $520 \mu \mathrm{m}$. At the end of the experience the final optical transmittances of the Exposed tube were divided by final optical transmittances of Control tube; so, the final optical transmittances of Control tube was assumed to be 1 .

After $8 \mathrm{~h}$ of exposure, the tubes labeled $\mathrm{C}$ and $\mathrm{E}$ were frozen and were carried for glucose measurement using enzymatic-colorimetric automation techniques (Selectra Merck ${ }^{\mathrm{TM}}$ ). The values of residual glucose quantity of the Exposed tubes were divided by the values of residual glucose quantity of Control tubes; so, the values of glucose in Control tubes were assumed to be 1 .

The procedure took place at a constant temperature of $28{ }^{\circ} \mathrm{C}$ and the 
inner coil's temperature was continuously monitored. It was observed that both temperatures had the same values.

The mean values were compared using the non-parametric MannWhitney U-test ${ }^{9}$, due to a sample size. The statistical significance was alpha $=5 \%$.

\section{RESULTS}

The glucose ratios in the Exposed and Control tubes are shown on Table 1, with smaller residual glucose in the Exposed tube $(0.90 \pm 0.06)$; it means that $E$. coli under EMF has an increase in glucose consume. Statistical analysis shown $\mathrm{U}=21.46(\mathrm{p}<0.001)$.

Table 1

Residual glucose in Exposed tubes (E. coli under 5G EMF) in ratio at Control tubes, as function of time. The values of Control tubes were normalized

\begin{tabular}{ccc}
\hline Tubes & Control & Exposed \\
\hline 1 & 1 & 0.96 \\
2 & 1 & 0.95 \\
3 & 1 & 0.98 \\
4 & 1 & 0.90 \\
5 & 1 & 0.90 \\
6 & 1 & 0.84 \\
7 & 1 & 0.89 \\
8 & 1 & 0.91 \\
9 & 1 & 0.92 \\
10 & 1 & 0.92 \\
11 & 1 & 0.76 \\
12 & 1 & 0.94 \\
13 & 1 & 0.89
\end{tabular}

$\mathrm{p}<0.001$ (Mann-Whitney U-test)

The final optical transmittances of tubes are $0.91 \pm 0.03$ for the Exposed and 1 for Control $(\mathrm{p}<0.001)$; the difference between the final records means that the smaller optical transmittance in the Exposed tubes is caused by the higher growth of E. coli colonies (Table 2). Statistical analysis shown $U=21.45(\mathrm{p}<0.001)$.

\section{DISCUSSION}

The higher turbidity of tubes with $E$. coli under EMF, after $8 \mathrm{~h}$ of exposure, could be due to increasing in generation of $E$. coli, since the initial optical transmittance had the same value in Exposed and Control tubes.

The cell initially experience a period of adjustment to the new environment and there is a lag in the time required for all cells to divide; this is referred as lag phase. Under favorable environment conditions there will be a exponential growth referred as $\log$ phase $^{5}$.

The action of EMF in exposed tubes with E. coli can be caused by the shortening of the lag phase and with more precocious start of log phase. Otherwise, at the end of the experiment we noticed that the log phase can be sustained for more time with a number more elevated of $E$.
Table 2

Final optical transmittance in Exposed tubes (E. coli under 5G EMF) in ratio at Control tubes. The values of Control tubes were normalized

\begin{tabular}{ccc}
\hline Tubes & Control & Exposed \\
\hline 1 & 1 & 0.96 \\
2 & 1 & 0.95 \\
3 & 1 & 0.97 \\
4 & 1 & 0.92 \\
5 & 1 & 0.91 \\
6 & 1 & 0.86 \\
7 & 1 & 0.89 \\
8 & 1 & 0.91 \\
9 & 1 & 0.90 \\
10 & 1 & 0.90 \\
11 & 1 & 0.89 \\
12 & 1 & 0.92 \\
13 & 1 & 0.89 \\
\hline
\end{tabular}

$\mathrm{p}<0.001$ (Mann-Whitney U-test)

coli colonies and with higher turbidity of tubes under EMF action.

In respect to glucose, the smaller contents of glucose in Exposed tubes can be due to the increasing of the transport of glucose into the bacteria.

Several mechanisms are involved in transport of growth solutes to inner cell. Narrow channels in outer membrane of E. coli facilitates passive diffusion of hydrophilic compounds as sugar, amino acids and certain ions to periplasm.

The Facility Diffusion, that occurs on behalf of the gradient, can have a carrier and this process could be excited by EMF and increasing the glucose transport. The EMF could stimulate the periplasm-binding protein-dependent transport system; these proteins work by transferring the bound substrate and it is energized by ATP or other high-energy phosphate compounds, such as acetyl phosphate ${ }^{5}$.

The chemiosmotic driven transport, in special the Symport type, can be stimulated resulting in an increasing in the glucose transport to the inner of E. coli ${ }^{5}$.

Other possibility could be special physical effects named mechanical, electrical or cyclotron resonances. The mechanical and electrical resonances have smaller effects in overture of pores to entrance of glucose. Thus, cyclotron resonance could be responsible for glucose's entrance, as happened with calcium ion ${ }^{1,10}$. This special resonance is represented by the equation $2 \pi v=\omega=q B / m$ where $\omega$ is the cyclotron resonance frequency, $q$ is the electron charge, $B$ is a magnetic field and $m$ is the mass of the ion. Unlike the mechanical resonance, energy in the cyclotron resonance is wholly stored in the kinetic energy of the circulating ion ${ }^{1}$.

In opposite to static magnetic field, dynamical magnetic field can generate electric fields which are more pervasive that the electric fields induced by external electric fields. It is possible that any biological events of interest may take place in the elements of the cells, not in the glucose ${ }^{1}$. 
The increased growth of $E$. coli under EMF could be important when it occurs in certain situations where there is the presence of $E$. coli in living being. These situations include patient with infection by $E$. coli, in the course of an hospital internment as in intensive care unit, when there is an exposition to several sources with electric activity, generating EMF. There are not citations on medical literature about this situation and, of course, this hypothesis can not be proved due to ethical aspects.

The EMF applied in E. coli in this study, was ten times the Earth EMF and effects of EMF smaller intensities must be studied to compare with these records.

\section{RESUMO}

\section{Consumo de glicose e crescimento de $E$. coli submetida a campo eletromagnético}

E. coli, em caldo glicosado, foi submetida a campo eletromagnético de intensidade $5 \mathrm{G}$, gerado por fonte de tensão alternada de $60 \mathrm{~Hz}$. Os crescimento e consumo de glicose foram avaliados através do teste nãoparamétrico de Mann-Whitney para comparação de dois grupos. Após 8 $\mathrm{h}$ de exposição encontraram-se menor valor da glicose residual e maior turbidez nos tubos expostos ao campo evidenciando efeito positivo deste. A causa deste efeito no consumo da glicose pode ser pela estimulação de sistema de transporte de glicose, como a Difusão Facilitada ou por um tipo de fenômeno chamado ressonância ciclotrônica. O aumento do crescimento pode ser pelo encurtamento da lag phase e estimulação da log phase.

\section{REFERENCES}

1. ADAIR, R.K. - Constraints on biological effects of weak extremely-low-frequency electromagnetic fields. Phys. Rev. A, 43: 1039-1048, 1991.
2. BLACKMAN, C.F.; BENANE, S.G.; ELLIOTT, D.J. \& POLLOCK, M.M. - Influence of electromagnetic fields on the efflux of calcium ions from brain tissue in vitro: a three-model analysis consistent with frequency response to $510 \mathrm{~Hz}$. Bioelectromagnetics, 9: 215-227, 1988.

3. GOODMAN, E.M.; GREENEBAUM, B. \& MARRON, M.T. - Magnetic fields after translation in Escherichia coli. Bioelectromagnetics, 15: 77-83, 1994.

4. LACY-HULBERT, A.; METCALFE, J.C. \& HESKETH, R. - Biological responses to electromagnetic fields. FASEB J., 12: 395-420, 1998.

5. MOAT, A.G. \& FOSTER, J.W. - Microbial Physiology, New York, Wiley-Liss, 1995. p. 335-337.

6. NASCIMENTO, L.F.C.; BOTURA Jr., G. \& MOTA, R.P. - Crescimento de E. coli submetida a campos magnéticos. In: Encontro Nacional de Física da Matéria Condensada, 19., Águas de Lindóia, 1996. Resumos. p. 281

7. PRESTON-MARTIN, S.; NAVIDI, W.; THOMAS, D. et al. - Los Angeles study of residential magnetic fields and childhood brain tumors. Amer. J. Epidem., 143: 105-119, 1996

8. SAVITZ, D.A.; LIAO, D.; SASTRE, A.; KLECKNER, R.C. \& KAVET, R. - Magnetic field exposure and cardiovascular disease mortality among electric utility workers. Amer. J. Epidem., 143: 135-142, 1999.

9. SIEGEL, S. \& CASTELLAN JR, N.J. - Nonparametric statistics for the behavioral sciences. 2. ed. New York, McGraw-Hill, 1998. p. 128-136.

10. SMITH, S.D; McLEOD, B.R.; LIBOFF, A.R. \& COOKSEY, K. - Calcium cyclotron resonance and diatom mobility. Bioelectromagnetics, 8: 215-227, 1987.

11. TUSCHL, H.; NEUBAUER, G.; SCHMID, G.; WEBER, E. \& WINKER, N. Occupational exposure to static, ELF, VF and VLF magnetic fields and immune parameters. Int. J. occup. Med. environ. Hlth., 13: 39-50, 2000.

Received: 27 December 2002

Accepted: 13 March 2003 